\title{
RESTRIÇÕES ÀS LIBERDADES: PRINCÍPIO DA PROPORCIONALIDADE COMO PROIBIÇÃO DE EXCESSO NA DOGMÁTICA DOS DIREITOS FUNDAMENTAIS ${ }^{1}$
}

\author{
Renata Camilo de Oliveira \\ Doutora em Direito pela Humboldt-Universität zu Berlin, Berlin, Alemanha. Mestre em \\ Direito Constitucional pela Universidade Federal de Minas Gerais, Belo Horizonte/MG, \\ e pela Ruprecht-Karls-Universität Heidelberg, Heidelberg, Alemanha. Sócia do escritório \\ FCR Law, São Paulo/SP.
}

\begin{abstract}
Resumo: Os direitos fundamentais não são absolutos, tampouco devem ser vistos como valores ponderáveis que tendem a colidir constantemente entre si e com outros valores. A partir destes pressupostos, o artigo apresenta uma pesquisa teórica de direito comparado, com análise de conteúdo da literatura alemã e brasileira sobre o princípio da proporcionalidade, relacionando-o com o modelo argumentativo para lidar com os direitos de defesa, denominado estrutura tríade. A hipótese que subjaz o trabalho é que ignorar a complexidade e as controvérsias relacionadas a esta estrutura, partindo para uma "ponderação de valores colidentes", significa um reducionismo, que suplanta o arsenal para a defesa das liberdades, amplia a discricionariedade dos órgãos aplicadores do direito e ignora as especificidades de cada direito fundamental. Como resultado, o artigo aborda uma estrutura argumentativa bastante complexa, que examina o âmbito de proteção e possíveis justificações de intervenções para os diferentes direitos de defesa, e que contém, inclusive, pontos controvertidos, merecedores de maior atenção doutrinária. Neste sentido, referida estrutura, ao invés de representar uma solução genérica, configura um mero arcabouço argumentativo, que deverá ser pensado e desenvolvido, de modo diferenciado, para cada um dos direitos fundamentais.
\end{abstract}

Palavras-chave: Direitos de defesa. Princípio da proporcionalidade. Estrutura tríade. Ponderação.

Sumário: Introdução - 1 Direitos de defesa contra intervenções estatais e proibição de excesso 2 Âmbito de proteção e intervenção nos direitos fundamentais - 3 Fundamento constitucional da intervenção: reserva de lei e direito fundamental colidente $\mathbf{- 4}$ Princípio da proporcionalidade como proibição de excesso e seus subprincípios - Conclusão - Referências

\section{Introdução}

Tornou-se corriqueiro afirmar, inclusive na jurisprudência do Supremo Tribunal Federal (STF), que os direitos fundamentais não são absolutos; que eles,

1 Parte dos resultados aqui apresentados foram coletados durante a realização de Doutorado, na HumboldtUniversität zu Berlin, com financiamento da Fundação Konrad Adenauer. 
ao colidirem com outros princípios ou valores, devem ser ponderados. Referido chavão tende, no entanto, a perder de vista que os direitos fundamentais são, na expressão de Dworkin, "trunfos"; trunfos do indivíduo contra o Estado; trunfos de minorias contra maiorias; trunfos que, apesar de gerarem problemas e dificuldades para as ações do Estado, não estão à disposição de nenhum dos poderes. A tensão entre estas duas perspectivas parece refletir um dilema central do direito constitucional: o Estado tem que regular as relações sociais e, na produção do direito, terá que, com frequência, intervir em nossas liberdades, mas, por outro lado, é vinculado pela Constituição, inclusive pelos direitos fundamentais, que, como normas de hierarquia superior, terão que ser respeitados na produção da legislação infraconstitucional. Buscando fazer jus a esta tensão, a ponderação conforme o princípio da proporcionalidade aparece como uma espécie de "fórmula mágica".2

A história jurídica do princípio da proporcionalidade radica-se na segunda metade do século XIX, na jurisprudência referente ao direito policial prussiano, sendo que sua função, na época, era o "mero" combate a excessos do poder estatal e contendo ele, então, apenas os critérios da adequação e da necessidade. $^{3}$ Desde a década de 1950 , ele ganhou, no entanto, por meio de impulso decisivo da jurisdição constitucional da Alemanha, enorme importância na dogmática dos direitos fundamentais daquele país e aparecendo, nesse contexto, intimamente acoplado a um novo componente: a ponderação. Com essa feição, a proporcionalidade se transformou, então, num grande “produto de exportação" do direito alemão, tendo sido, inclusive, integrada (especialmente a partir dos anos 1990 e, sobretudo, no atual século) ao direito brasileiro.

No entanto, como demonstra Laurentiis, é exatamente quando o princípio da proporcionalidade aparece vinculado à noção de colisão e de ponderação de valores, que ele perde seus contornos dogmáticos, gerando uma relativização dos próprios direitos fundamentais como parâmetros de controle. A proporcionalidade, lançada ao mar da ponderação, faz dos direitos fundamentais valores ou bens que tendem a constantes colisões entre si e com outros valores, levando ao "ponto zero" dogmático e perdendo exatamente sua função de proteção dos direitos de defesa. $^{4}$

STERN, Klaus. Das Staatsrecht der Bundesrepublik Deutschland. München: Beck, 2000. t. III/2. p. 817. Cf. HIRSCHBERG, Lothar. Der Grundsatz der Verhältnismäßigkeit. Göttingen: Otto Schwartz \& Co, 1981. p. 2 et seq.; STERN, Klaus. Das Staatsrecht der Bundesrepublik Deutschland. München: Beck, 2000. t. III/2. p. 765-767.

4 LAURENTIIS, Lucas Catib de. Proporcionalidade no direito constitucional: origem, modelos e reconstrução. São Paulo: Malheiros, 2017. p. 260 et seq. Neste sentido, já em 2002, ressaltava Silva, como a invocação da proporcionalidade, na jurisprudência do STF, possuía, com frequência, um caráter meramente retórico e não sistemático, e que o Tribunal não o aplicava de forma estruturada (SILVA, Virgílio Afonso da. 
Contra essa tendência, o presente artigo visa resgatar o sentido original do princípio da proporcionalidade, reintegrando-o na(s) dogmática(s) dos direitos fundamentais. Neste contexto, ele aparece como elemento central na justificação constitucional de intervenções nos direitos fundamentais como direitos de defesa e é exatamente aqui que se dissolve o paradoxo inicialmente apresentando (ainda que se mantenha a tensão entre Constituição e legislação infraconstitucional). Os direitos fundamentais não são absolutos, senão que, enquanto direitos de defesa, "apenas" proíbem intervenções não justificadas do Estado nas esferas individuais de liberdade. Obviamente, então, a questão central que se coloca é sobre o ônus argumentativo imposto ao Estado, isto é, da justificação que terá que satisfazer para intervir no âmbito de proteção dos direitos de defesa.

Em contraste com a "fórmula mágica" da ponderação de valores, que leva a uma perda dos contornos dogmáticos dos direitos fundamentais, o artigo propõe-se, assim, a abordar a integralidade do modelo argumentativo para lidar com restrições aos direitos de defesa (denominado estrutura tríade); um modelo bastante complexo, diferenciado e que, inclusive, possui aspectos controvertidos, merecedores de maior atenção doutrinária. Referida estrutura tríade, longe de representar uma solução genérica, configura um mero arcabouço argumentativo, que deverá ser pensado e desenvolvido para cada um dos direitos fundamentais. A proposta central, que permeia este arcabouço, é a de: partindo dos parâmetros estabelecidos pela Constituição para cada um dos direitos lá consagrados, reforçar a função de defesa dos direitos fundamentais, definindo critérios aos quais o legislador terá que atender para poder restringir, de modo legítimo, a nossa liberdade individual.

O artigo se divide em quatro partes. De início, é apresentada a chamada função de defesa dos direitos fundamentais e sua correlação com o princípio da proporcionalidade como proibição de excesso. Em seguida, aborda-se a denominada estrutura tríade (âmbitos de proteção, restrições a direitos fundamentais e limites às restrições) da dogmática dos direitos de defesa, incluindo uma crítica à noção de "valores constitucionais colidentes". Neste contexto, ficará claro como não há soluções genéricas para lidar com os diferentes direitos fundamentais, senão que é necessário o desenvolvimento de dogmáticas particulares. No que segue, o trabalho trata, então, especificamente, do princípio da proporcionalidade como proibição de excesso nos atos do Estado e de seus três subcritérios - adequação,

O proporcional e o razoável. Revista dos Tribunais, São Paulo, ano 91, n. 798, p. 23-50, abr. 2002. p. 31-34). Na presente análise, pretende-se, contudo, dar um passo além, indicando não apenas a necessidade do efetivo emprego dos três subcritérios, mas, ainda, de etapas preliminares, que devem ser desenvolvidas para cada direito fundamental e que, inclusive, influenciam a configuração do princípio da proporcionalidade. 
necessidade e proporcionalidade em sentido estrito. À guisa de conclusão, são retomadas, de forma sintética, as ideias centrais deste artigo atreladas às pretensões às quais a estrutura tríade pretende fazer jus.

\section{Direitos de defesa contra intervenções estatais e proibição de excesso}

Ainda que diversas funções sejam desenvolvidas e/ou atribuídas aos direitos fundamentais, estes surgiram, em primeiro plano, como direito de defesa contra intervenções estatais. Neste sentido, Thomas Humphrey Marshall, ao descrever a evolução histórica dos direitos, ressalta, exatamente, que: primeiro vieram os direitos civis, no século XVIII; depois, a partir do século XIX, inicia-se a expansão dos direitos políticos; e, finalmente, no século $X X$, passa-se à conquista dos direitos sociais. Importante observar que esta ordem, segundo o autor, não é apenas cronológica, mas também lógica: foi com base no exercício dos direitos civis, nas liberdades civis, que se reivindicou a expansão dos direitos políticos; e foi com base na participação política que se aprovaram os direitos sociais. ${ }^{5}$ Desta forma, o alicerce da evolução dos direitos foram as liberdades civis, isto é, os direitos fundamentais enquanto direitos de defesa - ainda que no Brasil este desenvolvimento tenha se dado com algumas peculiaridades. ${ }^{6}$

A tradicional função de defesa, de resistência ou de status negativus (na clássica teoria dos status de Jellinek) limita as possibilidades de atuação do Estado, na medida em que protege a esfera de liberdade (incluindo, aqui, a privacidade) do indivíduo contra intervenções do Poder Público. Os direitos fundamentais, enquanto direitos de defesa, fundamentam, assim, pretensões de abstenção ou, tendo a intervenção ocorrido, de sua supressão. Como ressaltam Dimoulis e

5 MARSHALL apud CARVALHO, José Murilo de. Cidadania no Brasil. O longo caminho. 3. ed. Rio de Janeiro: Civilização Brasileira, 2002. p. 220.

6 Ainda que, de uma perspectiva formal, a evolução dos direitos, no Brasil, tenha sido similar à trajetória descrita por Marshall, na prática, percebe-se certa inversão. Neste sentido, avalia Carvalho que, no Brasil, deu-se uma maior ênfase aos "direitos sociais, implantados em período de supressão dos direitos políticos e de redução dos direitos civis por um ditador que se tornou popular. Depois vieram os direitos políticos, de maneira também bizarra. A maior expansão do direito do voto deu-se em outro período ditatorial, em que os órgãos de representação política foram transformados em peça decorativa do regime. Finalmente, ainda hoje muitos direitos civis, a base da sequência de Marshall, continuam inacessíveis à maioria da população. A pirâmide dos direitos foi colocada de cabeça para baixo" (CARVALHO, José Murilo de. Cidadania no Brasil. O Iongo caminho. 3. ed. Rio de Janeiro: Civilização Brasileira, 2002. p. 219-220). Uma das principais consequências destas peculiaridades em relação ao desenvolvimento das diferentes espécies de direitos é a excessiva valorização do Poder Executivo e, até mesmo, a busca por um salvador da pátria, por um messias político. Ainda, como pontua Carvalho, a "contrapartida da valorização do Executivo é a desvalorização do Legislativo e de seus titulares, deputados e senadores” (p. 221-223). 
Martins, são direitos que permitem aos indivíduos resistir a uma possível atuação do Estado, que não deve interferir na esfera de liberdade individual. Sua essência está na proibição de interferência imposta ao Estado. Trata-se de um direito negativo, pois gera uma obrigação negativa endereçada ao Estado, a obrigação de deixar de fazer algo, de abster-se da intervenção na esfera de liberdade garantida pela Constituição. ${ }^{7}$ Assim, o Estado deve, e.g., abster-se de censurar a atividade jornalística, de impedir determinado culto, de invadir nosso domicílio, de violar a nossa correspondência etc.

Obviamente, a outra faceta desses direitos negativos é, exatamente, o exercício positivo dessas liberdades pelos indivíduos e/ou grupos - ainda que gere incômodos para outros indivíduos. Ocorre que o exercício desenfreado das liberdades pode levar a conflitos e, por isso, tem-se intervenções nos direitos fundamentais e são determinadas restrições a estes. Como, no entanto, a Constituição está no ápice da estrutura escalonada da ordem jurídica e não se encontra à disposição de nenhum dos poderes do Estado, a intervenção na liberdade submete-se, necessariamente, a uma avaliação de sua justificação constitucional. Assim, os direitos de defesa não proíbem toda e qualquer ingerência do Estado nas esferas individuais de liberdade, senão que proíbem "somente" as intervenções não justificadas.

É exatamente neste contexto que a clássica e principal configuração ${ }^{8}$ do princípio da proporcionalidade ganha relevo, isto é, como proibição de excesso (Übermaßverbot) em face de intervenções estatais na liberdade ou privacidade. $\mathrm{Na}$ condição de limite a restrições a direitos fundamentais, o princípio da proporcionalidade desempenha papel decisivo na questão da justificação de intervenções - legais ou com base em lei - nos direitos fundamentais. 0 legislador pode intervir no âmbito de proteção dos direitos fundamentais somente quando a intervenção estiver coberta pela Constituição e não violar o princípio da proporcionalidade. Sendo a intervenção originária da Administração Pública ou do

DIMOULIS, Dimitri; MARTINS, Leonardo. Teoria geral dos direitos fundamentais. 2. ed. São Paulo: Revista dos Tribunais, 2009. p. 55-56.

8 Ao lado da clássica aplicação do princípio da proporcionalidade como proibição de excesso, em um movimento bem recente, tem-se buscado expandir e adaptar o teste da proporcionalidade para duas outras situações: como proibição de omissão diante da função de proteção dos direitos fundamentais (Untermaßverbot) e como restrição a tratamentos discriminatórios relacionada ao direito à igualdade. Cf., a propósito, MICHAEL, Lothar. Die drei Argumentationsstrukturen des Grundsatzes der Verhältnismäßigkeit - Zur Dogmatik des Über- und Untermaßverbotes und der Gleichheitssätze. Juristische Schulung (JuS), München e Frankfurt a.M, ano 41, n. 2, p. 148-155, fev. 2001. Na literatura brasileira, sobre a diferenciação entre proibição de excesso e proibição de insuficiência, cf. SILVA, Virgílio Afonso da. O proporcional e o razoável. Revista dos Tribunais, São Paulo, ano 91, n. 798, p. 23-50, abr. 2002. p. 27. Uma tentativa de aplicar a estrutura aqui apresentada também para direitos de prestação e para a função de proteção encontra-se em SILVA, Virgílio Afonso da. Direitos fundamentais: conteúdo essencial, restrições e eficácia. 2. ed. São Paulo: Malheiros, 2010. p. 76-78; 235 et seq. 
Judiciário, ela deve ter uma lei como base, que corresponda a essas condições. ${ }^{9}$ o princípio da proporcionalidade, como proibição de excesso, exige, em suma, que o poder estatal interventor persiga sua meta de forma adequada, necessária e proporcional.

Segundo o modelo que passamos a apresentar, antes da aplicação da proporcionalidade (limite à restrição), devem, no entanto, ser, previamente, trabalhados o âmbito de proteção do direito fundamental e suas restrições. De fato, essa dogmática dos direitos fundamentais, também denominada "estrutura tríade" (âmbito de proteção, restrições a direitos fundamentais e limite às restrições) é marcada, sobretudo, pelo confronto entre âmbito de proteção e restrição. Assim, como pontua Böckenförde, o primeiro passo na aplicação das normas de direitos fundamentais é sempre a verificação e a delimitação do seu âmbito de proteção, o que deve ser feito de modo diferenciado para cada direito fundamental. Posteriormente, é constatado se, e em que medida, um ato do Estado representa uma intervenção no âmbito de proteção. Sendo a intervenção confirmada, devem ser averiguadas suas possíveis justificativas, isto é, se, e em que medida, existe um fundamento constitucional para a intervenção (chamado de restrição), sendo que, também aqui, para os diferentes direitos fundamentais existem diferentes autorizações para intervenções. ${ }^{10}$ Somente após estas etapas e desde que exista um fundamento para a intervenção, o princípio da proporcionalidade é trazido à discussão.

\section{2 Âmbito de proteção e intervenção nos direitos fundamentais}

Nos diversos âmbitos da vida, os direitos fundamentais protegem os indivíduos, primeiramente, contra intervenções não justificadas do Estado (função de defesa). A respectiva esfera da vida protegida por um direito fundamental é considerada sua área ou seu âmbito de proteção (Schutzbereich), o qual denomina,

STERN, Klaus. Das Staatsrecht der Bundesrepublik Deutschland. München: Beck, 2000. t. III/2. p. 791.

10 BÖCKENFÖRDE, Ernst-Wolfgang. Schutzbereich, Eingriff, verfassungsimmanente Schranken: Zur Kritik gegenwärtiger Grundrechtsdogmatik. Der Staat, Berlim, v. 42, n. 1-4, p. 165-192, 2003. p. 166. Na doutrina brasileira, percebe-se certa tendência de recepção da completude deste modelo argumentativo, consoante se pode extrair de sua apresentação, inclusive, em manuais de curso, como, e.g.: SARLET, Ingo Wolfgang; MARINONI, Luiz Guilherme; MITIDIERO, Daniel. Curso de direito constitucional. 7. ed. São Paulo: Saraiva, 2018. p. 385-405; MENDES, Gilmar Ferreira; COELHO, Inocêncio Mártires; BRANCO, Paulo Gustavo Gonet. Curso de direito constitucional. 12. ed. São Paulo: Saraiva, 2017. p. 190-234. Estes manuais, ao tratarem dos direitos em espécie, são, contudo, também ilustrativos da inclinação generalizante da lógica da ponderação, especialmente, em relação às restrições dos direitos fundamentais e ao papel da legislação infraconstitucional na resolução das chamas "colisões". 
assim, a fração da realidade, na qual a proteção deve operar. Em outras palavras, a área de proteção é o âmbito das “ações, estados ou posições jurídicas” protegidas por um direito fundamental. ${ }^{11}$ Ela é, ainda, diferenciada da garantia do direito fundamental (Grundrechtsgewährleistung), que se refere ao efeito protetor delimitado pelo direito. ${ }^{12} \mathrm{Um}$ direito fundamental tem, por conseguinte, o seu âmbito de proteção, e garante neste âmbito um direito subjetivo (direito de defesa, de proteção, de participação ou de prestação).

Enquanto direito de defesa, garante, assim, por exemplo, a "inviolabilidade do direito à vida", basicamente, a existência física e corpórea de seus titulares contra intervenções injustificadas do Estado. Similarmente, se dá com o art. 5ํ, IV, da CRFB, que assegura, entre outras faculdades, a livre expressão de juízos de valor e de opiniões; ou com o art. 5ำ XII, da CRFB, que garante que determinadas formas de comunicação humana, realizadas com a ajuda de meios técnicos de maior ou menor sofisticação, ocorram com privacidade, isto é, sem interferências alheias à vontade dos correspondentes ou interlocutores etc.

Nesta primeira etapa, portanto, a respectiva esfera da vida e o conteúdo de proteção ou de garantia do direito fundamental são delineados. Apesar de controvérsias, segundo a doutrina majoritária, nos direitos de liberdade, aponta a proteção da liberdade em sentido abrangente, de forma que o titular do direito fundamental pode se comportar, em relação ao respectivo âmbito da vida, discricionariamente, isto é, como bem desejar (liberdade no sentido subjetivo). ${ }^{13}$

11 BOROWSKI apud SILVA, Virgílio Afonso da. Direitos fundamentais: conteúdo essencial, restrições e eficácia. 2. ed. São Paulo: Malheiros, 2010. p. 72.

12 PIEROTH, Bodo; SCHLINK, Bernhard. Direitos fundamentais. São Paulo: Saraiva, 2012. p. $116-117$.

13 Cf., e.g., ALEXY, Robert. Theorie der Grundrechte. Frankfurt a.M: Suhrkamp, 1994. p. 155; 202 et seq. Cumpre ressaltar, no entanto, a existência de controvérsia na doutrina no que diz respeito à delimitação do âmbito de proteção. Alexy e os que adotam sua teoria tendem a partir de uma concepção abrangente do âmbito de proteção. Cf., neste sentido, o contraponto, traçado por Silva, entre as noções de suporte fático restrito e suporte fático amplo: SILVA, Virgílio Afonso da. Direitos fundamentais: conteúdo essencial, restrições e eficácia. 2. ed. São Paulo: Malheiros, 2010. p. 79 et seq. Comparação similar e a defesa de uma teoria do suporte fático amplo pode ser encontrada em ALEXY, Robert. Theorie der Grundrechte. Frankfurt a.M: Suhrkamp, 1994. p. 273 et seq. Como salienta, no entanto, Böckenförde, tal enfoque dogmático agrava o problema das restrições e acarreta a necessidade de um arsenal de restrições imanentes à Constituição e ponderações (BÖCKENFÖRDE, Ernst-Wolfgang. Schutzbereich, Eingriff, verfassungsimmanente Schranken: Zur Kritik gegenwärtiger Grundrechtsdogmatik. Der Staat, Berlim, v. 42, n. 1-4, p. 165-192, 2003. p. 167). De fato, tendo em vista que a Constituição não apenas consagra um direito fundamental à liberdade geral de ação, mas também especifica distintos direitos fundamentais em espécie, deve o intérprete levar a sério esta diferenciação e buscar delimitar o que é abrangido por cada um dos distintos âmbitos de proteção. Como ressaltam Pieroth e Schlink, nenhuma presunção constitui argumento a favor do alargamento ou do estreitamento dos âmbitos de proteção de cada um dos diferentes direitos fundamentais. Estes "têm de ser simplesmente determinados de maneira correta com os meios jurídicos normais de interpretação, a partir de seu texto, da sua história, da sua gênese e da sua posição sistemática" (PIEROTH, Bodo; SCHLINK, Bernhard. Direitos fundamentais. São Paulo: Saraiva, 2012. p. 126). Neste sentido, para uma defesa de uma delimitação acurada e fundamentada do âmbito de proteção de cada um dos direitos fundamentais em espécie, levando em conta o âmbito fatual 
A liberdade jurídica seria, assim, a autorização jurídica de fazer ou deixar de fazer o que se quiser. Esse comportamento livre e discricionário, que abrange tanto a ação, como a omissão e o mero estar, pode ser denominado exercício dos direitos fundamentais. Entretanto, o exercício sem limites das liberdades ou dos demais direitos fundamentais, em que o indivíduo pode fazer ou deixar de fazer o que bem entender, pode levar a conflitos com direitos fundamentais de terceiros ou mesmo com o chamado interesse público. Por essa razão, há intervenções nos direitos fundamentais, e determinam-se restrições ao seu exercício. Fica, assim, estabelecida a correlação entre âmbito de proteção e intervenção, entre ambos existe indissociável enlace, eles se remetem respectivamente.

Tem-se uma limitação, ingerência ou intervenção (Eingriff) estatal sempre que uma lei, um ato administrativo ou uma decisão judicial atuar de forma restritiva no âmbito de proteção de um direito fundamental. Ou seja, intervenções podem ser tanto gerais (lei, decreto, outro tipo de regulamento) como individuais (ato administrativo, sentença judicial). Uma intervenção é, por conseguinte, todo ato do Estado que dificulta ou impede, total ou parcialmente, ao indivíduo um comportamento abrangido pelo âmbito de proteção de um direito fundamental; sendo indiferente se essa interferência foi intencional ou involuntária, direta ou indireta, de fato ou de direito e se ocorreu com ou sem ordem ou coação. ${ }^{14}$

Tendo em vista, no entanto, a supremacia constitucional, o Estado, para levar a cabo uma intervenção, sempre necessita de uma justificação constitucional. Se a justificação for suficiente, isto é, se satisfizer o ônus argumentativo que será aqui apresentado, a intervenção será constitucional; caso contrário, será inconstitucional, ou seja, representará uma violação ao respectivo direito fundamental. 0 primeiro passo de referida justificação é a busca de um fundamento constitucional para a intervenção, também denominado restrição.

\section{Fundamento constitucional da intervenção: reserva de lei e direito fundamental colidente}

Em face da supremacia constitucional, as normas da Constituição não estão à disposição de nenhum dos poderes do Estado, nem mesmo do Legislativo.

(Sachbereich) e diferentes meios interpretativos, cf. MÜLLER, Friedrich. Die Positivität der Grundrechte: Fragen einer praktischen Grundrechtsdogmatik. 2. ed. Berlim: Duncker \& Humblot, 1990; OLIVEIRA, Renata Camilo de. Zur Kritik der Abwägung in der Grundrechtsdogmatik: Beitrag zu einem liberalen Grundrechtsverständnis im demokratischen Rechtsstaat. Berlim: Duncker \& Humblot, 2013. p. 292 et seq.

14 PIEROTH, Bodo; SCHLINK, Bernhard. Direitos fundamentais. São Paulo: Saraiva, 2012. p. $128-129$. 
Assim, todo o ordenamento infraconstitucional deve estar em consonância com a Constituição, sob pena de inconstitucionalidade e, portanto, nulidade. ${ }^{15}$ Ora, se os direitos fundamentais vinculam o Estado, só podem "estar em consonância" com a Constituição e, assim, ser passível de justificação, a intervenção (ou limitação) autorizada pela própria Constituição. Em outras palavras, a intervenção deve configurar-se como a "proporcional concretização de um limite previsto pela própria Constituição". ${ }^{16}$

O primeiro passo na análise da justificação constitucional é, portanto, exatamente, a busca por referida autorização constitucional ou, em outras palavras, de um fundamento constitucional para a intervenção, que é chamada no modelo aqui apresentado de restrição (Schranke). ${ }^{17}$ Uma análise cuidadosa das restrições de cada direito fundamental é um aspecto central da estrutura aqui apresentada, afinal "quanto mais livre o legislador para fixar o fim de sua produção normativa, tanto mais fraca a eficácia do princípio da proporcionalidade". ${ }^{18}$ Contudo, apesar de muitos esforços, não se pode dizer que exista, nem mesmo na dogmática alemã, uma sistemática satisfatória das restrições. ${ }^{19}$ É incontroverso que existe tal autorização para intervenção (restrição) nos direitos fundamentais positivados com uma reserva de lei; havendo, por outro lado, divergências em relação aos direitos sem reserva de lei.

As reservas de lei (Gesetzesvorbehalt) são determinações constitucionais que autorizam o legislador a intervir no âmbito de proteção do respectivo direito fundamental, e exigem, simultaneamente, autorização legal para uma intervenção da Administração Pública nos direitos fundamentais. Partindo da tradicional divisão de José Afonso da Silva, os direitos fundamentais que possuem referida

15 Assim, mostra-se incompatível com a concepção aqui defendida e, a nosso ver, com a noção de supremacia constitucional, a perspectiva que pretende a priori excluir ilícitos penais da proteção dos direitos fundamentais. Neste sentindo, e.g.: "A invocação da liberdade religiosa, de seu turno, não pode servir de pretexto para a prática de atos que se caracterizam como ilícitos penais" (MENDES, Gilmar Ferreira; COELHO, Inocêncio Mártires; BRANCO, Paulo Gustavo Gonet. Curso de direito constitucional. 12. ed. São Paulo: Saraiva, 2017. p. 319) - como se o direito fundamental tivesse que estar em consonância com a legislação penal e não o contrário.

16 DIMOULIS, Dimitri; MARTINS, Leonardo. Teoria geral dos direitos fundamentais. 2. ed. São Paulo: Revista dos Tribunais, 2009. p. 135.

17 Nesse sentido, Alexy designa o conceito de intervenção como um supraconceito para os termos: “impedimento", "detrimento" ou "prejuízo", e o diferencia do conceito de restrição como justificativa da intervenção. Logo, uma intervenção que não seja justificada por meio de uma restrição é proibida pelo direito fundamental de forma definitiva (ALEXY, Robert. Theorie der Grundrechte. Frankfurt a.M: Suhrkamp, 1994. p. 174 et seq., 277). A restrição é, portanto, a primeira parte da justificação da intervenção.

18 BONAVIDES, Paulo. O princípio constitucional da proporcionalidade e da proteção dos direitos fundamentais. Revista da Faculdade Livre de Direito do Estado de Minas Gerais, Belo Horizonte, v. 34, n. 34, p. 275-291, 1994. p. 287.

19 ALEXY, Robert. Theorie der Grundrechte. Frankfurt a.M: Suhrkamp, 1994. p. 258. 
autorização enquadram-se, portanto, como normas constitucionais de eficácia contida. Quando a Constituição concede ao legislador, de forma expressa, essa competência, ele pode, assim, restringir o âmbito de proteção de um direito fundamental, mas não discricionariamente, senão que, como abordaremos, com um ônus argumentativo imposto pelo princípio da proporcionalidade - caso contrário, ele não estaria vinculado às normas de direito fundamental.

Existem reservas de lei simples e qualificadas. A simples (também denominada ordinária, plena ou absoluta) está presente nos direitos fundamentais, em que a intervenção deve ocorrer meramente por ou com base em lei, sem que sejam impostas maiores exigências à respectiva legislação restritiva, como, e.g., no art. 5ㅇ, II, XV e XVIII da CRFB. Ela concede, em princípio, uma ampla autorização, ao legislador, para intervenções. Por sua vez, configura-se uma reserva legal qualificada (também chamada de limitada ou relativa) nos casos em que a Constituição não apenas autoriza que a intervenção ocorra por ou com base em lei, mas também traz limitações ao seu conteúdo e exige que a intervenção esteja relacionada a situações específicas, que sirva a certos objetivos ou que utilize determinados meios, ${ }^{20}$ como no art. 5으, XII e XIII da CRFB.

Para grande parte dos direitos fundamentais, a Constituição de 1988 não prevê, contudo, qualquer possibilidade de intervenção por meio de lei ou com base em lei (e.g., na liberdade religiosa ou na liberdade artística). Referidos direitos fundamentais foram, portanto, positivados, sem reservas de lei, e constituem, na clássica divisão de José Afonso da Silva, normas constitucionais de eficácia plena. Contudo, também esses direitos fundamentais sem reserva não são garantidos sem restrições, pois similarmente aqui um exercício desenfreado das liberdades pode levar a conflitos. Assim, existe certo consenso no sentido de que nem tudo o que possa ser trazido, de qualquer forma, sob o tipo legal das normas garantidas sem reserva de lei será protegido pelo direito fundamental. ${ }^{21} \mathrm{~A}$ ausência de reserva de lei indica, no entanto, que o legislador não teria qualquer espaço para julgar e combater o perigo de conflitos.

A dogmática majoritária, tanto na Alemanha, como no Brasil, tenta resolver esse paradoxo desenvolvendo a noção de restrições a direitos fundamentais imanentes à Constituição (verfassungsimmanente Schranken der Grundrechte). A ideia da unidade da Constituição exige que nenhum direito fundamental seja visto de forma isolada, pois, caso contrário, isso poderia ir às custas de outras

20 PIEROTH, Bodo; SCHLINK, Bernhard. Direitos fundamentais. São Paulo: Saraiva, 2012. p. 131.

21 Cf. ALEXY, Robert. Theorie der Grundrechte. Frankfurt a.M: Suhrkamp, 1994. p. 107; MENDES, Gilmar Ferreira; COELHO, Inocêncio Mártires; BRANCO, Paulo Gustavo Gonet. Curso de direito constitucional. 12. ed. São Paulo: Saraiva, 2017. p. 208. 
garantias constitucionais. ${ }^{22}$ Daí, terem jurisprudência e doutrina majoritária desenvolvido, para intervenções não previstas, a justificativa com base em direitos ou valores constitucionais colidentes. Isso significa que os direitos fundamentais sem reserva, quando o seu exercício colidir com outro direito fundamental ou demais bens ou valores constitucionais, podem ser restringidos através de uma ponderação no caso concreto, em que a norma constitucional colidente serve como justificativa da intervenção.

Ainda que o escopo da presente contribuição não seja desenvolver uma abrangente discussão sobre a noção de valor ou direito constitucional colidente, cabe ressaltar ser este um dos pontos em que a tendência generalizante da teoria das colisões e ponderações se mostra de modo mais claro. Nesta teoria, a Constituição passa a ser vista como uma ordem de valores, sujeita a constantes colisões, a serem resolvidas por meio da ponderação de bens. Esta concepção traz, no entanto, riscos tanto para própria proteção dos direitos fundamentais, como para a divisão de atribuições entre legislador democrático e jurisdição constitucional.

Neste sentido, é questionável quantos "bens" podem ser facilmente estilizados como valor constitucional e, portanto, quantas colisões podem ser geradas. Afinal, uma "colisão" pode ser gerada artificialmente e é, em qualquer caso, o resultado de uma interpretação ou, por vezes, uma renúncia à interpretação. De fato, o atual modelo dominante tende a partir de uma definição bem ampla do âmbito de proteção, a se abster de demonstrar qual o princípio "conflitante" e, em vez disso, permitir que uma "colisão" genericamente considerada e com qualquer tipo de interesse (inclusive o estatal) seja suficiente para relativizar os direitos fundamentais. Além disso, essa compreensão possibilita uma ampla adoção quando não produção -, pela jurisdição, de bens ou valores que são contrapostos aos direitos fundamentais e que, com frequência, sequer possuem uma base específica no texto constitucional. ${ }^{23}$

22 MICHAEL, Lothar. Die drei Argumentationsstrukturen des Grundsatzes der Verhältnismäßigkeit - Zur Dogmatik des Über- und Untermaßverbotes und der Gleichheitssätze. Juristische Schulung (JuS), München e Frankfurt a.M, ano 41, n. 2, p. 148-155, fev. 2001. p. 150.

23 Ajurisprudência do STFé, quanto a este aspecto, de fato, pródiga no reconhecimento de bens constitucionais colidentes, muitas vezes, "derivando" bens sem sequer indicar o seu fundamento constitucional. Cf., e.g., a estabilidade econômica na ADI-MC no 223, p. 49; 63 et seq.; 80. DJ, 29 jun. 1990 (Plano Collor); a defesa dos animais em RE no 153.531, p. 388 et seq. DJ, 13 mar. 1998 (Farra do Boi); o fornecimento de energia elétrica em $A D C$ no 9, p. 26 et seq.; 49 et seq. DJ, 23 abr. 2004 (Apagão); a situação financeira dos estados e a reserva do possivel em IF no 2915-5, p. 182 et seq. DJ, 28 nov. 2003; a manutenção da previdência social em ADI no 3.105, p. 168; 251; 320. DJ, 18 fev. 2005 (EC o 41/2003); a ordem pública e o poder-dever de punir do Estado em Inq. no 2.424 de 26.11.2008. Informativo, n. 529, 2008 (Medina, Alvim e outros). 
Ainda, as restrições através de bens constitucionais colidentes são compreendidas, com frequência, não apenas como possibilidades de restrições admitidas, que o legislador eventualmente pode realizar, mas como restrições já diretamente válidas e, como tais, efetivas. Consequentemente, os tribunais podem aplicar essas restrições sem que necessitem de autorização por parte do legislador. No lugar das reservas de lei entra, assim, por meio das restrições imanentes à Constituição, uma delegação para o Executivo com reserva do Judiciário, a qual é exercida, por fim, através da interpretação e ponderação da jurisdição constitucional. ${ }^{24}$ Assim, ficam óbvias a ampliação da margem de discricionariedade da decisão judicial e a relativização da força normativa dos direitos fundamentais. Estes perdem sua estrita primazia em relação aos argumentos não jurídicos, e a decisão judicial afrouxa sua estrita vinculação legal.

Em contraposição a este modelo, numa posição mais restritiva, consideramos que a intervenção a um direito fundamental sem reserva de lei só é possível com respaldo em lei, ${ }^{25}$ que vise proteger um direito fundamental colidente (e, não, qualquer "bem" constitucional). Os direitos fundamentais devem ser concebidos, em face do pluralismo social, como trunfos contra argumentos utilitaristas e orientações axiológicas. ${ }^{26}$ É neste sentido que Dworkin, por exemplo, adota um conceito de princípio mais restritivo, definindo como argumentos de princípios os que estabelecem direitos individuais, sendo que estes possuem primazia em relação ao que ele denomina políticas (policies), isto é, argumentos relacionados a bens coletivos. Isto não significa que, necessariamente, todo e qualquer direito, no contexto de fundamentações concretas, consegue se impor sobre todo e

24 BÖCKENFÖRDE, Ernst-Wolfgang. Zur Lage der Grundrechtsdogmatik nach 40 Jahren Grundgesetz. München: Carl Friedrich von Siemens Stiftung, 1990. p. 21-22. A tendência aqui discutida de uma ampla adoção de valores constitucionais colidentes, cuja implementação independe da atuação do legislador infraconstitucional, mostra-se, como apontado (cf. nota 10 supra), bastante presente na doutrina pátria. Cf., neste sentido, MASTRODI, Josué. Ponderação de direitos e proporcionalidade das decisões judiciais. Revista Direito GV, v. 10, p. 577-595, 2014. Referido autor destaca, como virtude central da teoria dos direitos fundamentais de Robert Alexy, o fato de esta teoria reconhecer "que todo princípio normativo - identificado como direito fundamental ou preceito constitucional - representa um valor ou interesse socialmente relevante" (p. 583). Consequentemente, “a solução de um conflito real, no âmbito de um Estado de Direito, será solucionado a partir da conformação dos direitos fundamentais contrapostos em jogo, em cada caso concreto. A tábua de valores preestabelecida no ordenamento jurídico deixa de ser critério para estabelecer decisões quando o conflito entre partes envolver direitos fundamentais" (p. 582).

25 Como ressaltam Dimoulis e Martins, os poderes executivos e judiciários estão submetidos ao império da lei. A exigência de que a restrição com base em direito constitucional colidente se dê por ou com base em lei oferece, neste sentido, vantagens tanto da perspectiva democrática, como tendo em vista a segurança jurídica (DIMOULIS, Dimitri; MARTINS, Leonardo. Teoria geral dos direitos fundamentais. 2. ed. São Paulo: Revista dos Tribunais, 2009. p. 143). Similarmente, consideram Pieroth e Schlink que a restrição de um direito fundamental sem reserva, com certeza, não pode se dar sob pressupostos menos exigentes do que naqueles consagrados com reserva, não sendo, assim, justificável jurídico-constitucionalmente a intervenção num direito fundamental sem reserva que não tenha lugar por ou com base numa lei (PIEROTH, Bodo; SCHLINK, Bernhard. Direitos fundamentais. São Paulo: Saraiva, 2012. p. 155).

26 DWORKIN, Ronald. Taking rights seriously. Cambridge, Mass.: Harvard University Press, 1977. 
qualquer bem coletivo. A primazia de uma meta coletiva deve, porém, nesse caso, ser justificada à luz de princípios. ${ }^{27}$

De qualquer forma, seja com base em uma reserva de lei, seja com base em um direito fundamental colidente (ou, mesmo, em um direito constitucional colidente), restrições a direitos fundamentais não podem ocorrer discricionariamente e não podem jamais significar uma completa supressão da proteção do direito fundamental, pois, caso contrário, esvaziar-se-ia a vinculação aos direitos fundamentais. Tendo em vista que tanto o legislador, como os demais poderes do Estado são vinculados às normas de direitos fundamentais, as restrições sujeitam-se, por sua vez, a limitações e, por isso, realiza-se uma avaliação da admissibilidade das restrições. Trata-se aqui, portanto, de limites à restringibilidade e, dessa forma, fala-se de limites às restrições ou restrições das restrições (Schranken-Schranken).

$\mathrm{Na}$ dogmática constitucional alemã, o princípio da proporcionalidade não é a única limitação existente. ${ }^{28} \mathrm{~A}$ vinculação às normas de direitos fundamentais é, no entanto, trabalhada pelo Tribunal Constitucional alemão (BVerfG) principalmente através do princípio da proporcionalidade, que, conforme exposto, tem experimentado, atualmente, ampla aplicação também pelo STF. Por conseguinte, esse princípio desempenha, tanto na Alemanha, como no Brasil, um papel decisivo para a questão da justificação de intervenções em direitos fundamentais. Ele é considerado a principal limitação para todas as restrições a direitos fundamentais, ${ }^{29}$ e as reservas de leis nas determinações dos direitos fundamentais são vistas, na prática, como "reserva de lei proporcional”. 30

\section{Princípio da proporcionalidade como proibição de excesso e seus subprincípios}

Trata-se, no princípio da proporcionalidade, de uma análise da relação entre meios e fins de atos do Estado. Ele exige que uma intervenção num direito

27 HABERMAS, Jürgen. Faktizität und Geltung: Beiträge zur Diskurstheorie des Rechts und des demokratischen Rechtsstaats. Frankfurt a.M.: Suhrkamp, 1998. p. 254; 315.

28 Sob o conceito dos limites às restrições, são abrangidos, via de regra, também, os seguintes limites: a garantia do núcleo essencial (Wesensgehaltsgarantie); a proibição de lei restritiva especial (ou seja, para um caso ou pessoa); o mandado de citação (que exige a expressa indicação do direito fundamental restringido) e a exigência inerente ao Estado de Direito de que as leis exprimam o tipo legal e a consequência jurídica de forma clara e determinada (princípio da determinação - Bestimmtheitsgrundsatz). Para explicações sobre estes limites às restrições, cf. PIEROTH, Bodo; SCHLINK, Bernhard. Direitos fundamentais. São Paulo: Saraiva, 2012. p. 146-151.

29 STERN, Klaus. Das Staatsrecht der Bundesrepublik Deutschland. München: Beck, 2000. t. III/2. p. 764, 788.

30 PIEROTH, Bodo; SCHLINK, Bernhard. Direitos fundamentais. São Paulo: Saraiva, 2012. p. 135. 
fundamental (meio) seja adequada, necessária e conveniente (ou proporcional em sentido estrito) para alcançar uma meta, que, por sua vez, também deve ser constitucional. A avaliação da proporcionalidade remete, assim, a posições jurídicas atingidas concretamente. Diante do caso, deve-se, então, identificar e analisar o meio e o fim, assim como os três elementos constitutivos ou subcritérios da proibição de excesso, quais sejam: a adequação, a necessidade e a proporcionalidade em sentido estrito.

\subsection{Licitude do fim perseguido e do meio empregado}

Antes do exame dos três subcritérios, o meio utilizado e o fim perseguido pelo poder estatal (que está a restringir um direito fundamental) já devem, porém, necessariamente, ser lícitos, isto é, não proibidos pela Constituição ou, conforme o caso, se a análise for de ato infralegal, condizente com a determinação legal. Assim, não é possível ao Estado, e.g., cercear a liberdade de expressão em prol de uma posição ideológica "oficial"; em qualquer hipótese, promover determinada religião "oficial" (art. 19, I da CRFB); ou, ainda, em prol da segurança pública, estabelecer a pena de morte (art. 5ㅇ, XLVII da CRFB).

Cumpre reconhecer, no entanto, que são poucos os fins ou meios vedados constitucionalmente, de forma que, na maioria dos casos, a constitucionalidade das leis não é colocada em xeque neste ponto da análise. Contudo, o caráter produtivo desses primeiros passos reside também na definição, com precisão e clareza, do fim perseguido pela intervenção e dos meios utilizados para tanto - devendo-se, inclusive, refutar definições genéricas, sob pena de o princípio da proporcionalidade perder sua capacidade de condução. ${ }^{31}$ Além disso, também neste ponto cumpre observar a necessidade de se desenvolver uma dogmática especial para cada um dos direitos fundamentais, afinal existem requisitos específicos quanto aos meios e fins para os diferentes direitos fundamentais. Exemplar, neste sentido, é a jurisprudência do BVerfG em relação à liberdade de expressão. O Tribunal considera que a qualquer regulação estatal sobre a disputa e o conflito de opiniões deve, necessariamente, também buscar preservar a diversidade e abertura desta disputa (Cf. BVerfGE 7, 198/ 207 et seq.; 25, 256/265; 62, 230/247; 61, 1/9).

Além disso, até certo ponto, são usados diferentes parâmetros no controle da proporcionalidade de leis e de medidas da Administração Pública ou do Judiciário.

31 DIMOULIS, Dimitri; MARTINS, Leonardo. Teoria geral dos direitos fundamentais. 2. ed. São Paulo: Revista dos Tribunais, 2009. p. 184. 
Isso já vale para a avaliação dos meios e fins escolhidos. Nesta escolha, o Legislativo tem uma liberdade consideravelmente maior que a Administração ou a Jurisdição. Para a Administração, já são predeterminadas, por lei, as metas a serem perseguidas, e o Judiciário é, ainda de forma mais estrita, obrigado a encontrar a solução para um caso concreto a partir de um direito previamente dado. Em contraste, o legislador pode, em princípio, fixar autonomamente, nos limites da Constituição, as metas de seu agir, assim como o meio a ser empregado. No que se refere, contudo, aos direitos fundamentais sem reserva de lei, metas legítimas são, segundo o modelo aqui defendido, somente a realização de direito fundamental colidente e, não, qualquer interesse público - desde que, por certo, não se siga a tendência apresentada de derivar um sem número de bens como tendo status constitucional e que possam justificar a restrição.

Já neste contexto, cumpre enfatizar um aspecto central do princípio da proporcionalidade: a obrigatoriedade de que haja uma razão, um fim perseguido para que se justifique a restrição da liberdade. Isto significa que o Estado e, similarmente, maiorias políticas não podem restringir a liberdade, paternalisticamente, porque considera que a conduta não é digna, boa, moral, que não é correta a opção de vida etc. Neste sentido, o princípio da proporcionalidade remete a um aspecto central dos direitos fundamentais, ao direito à diferença, ao pluralismo social que os direitos fundamentais devem possibilitar, à proteção de minorias e suas opções de vida. Ainda, a existência de uma meta (coberta pela reserva de lei ou decorrente de direito fundamental colidente) não garante, por si só, a constitucionalidade do meio, senão que ela deverá também ser perseguida de modo racional do ponto de vista fático, isto é, proporcional, no sentido que se passa a explanar.

\subsection{Adequação: relação meio-fim}

A adequação (Geeignetheit, esporadicamente também denominada aptidão ou idoneidade - Tauglichkeit) exige somente uma conexão empírica entre o meio e o fim, isto é, que o meio fomente a meta; que, de algum modo, a promova. É adequado, então, um meio ou medida quando a restrição ao direito fundamental aumenta a probabilidade de se alcançar a meta almejada. Nesse sentido, pontua Sarmento:

O subprincípio da adequação preconiza que a medida administrativa ou legislativa emanada do Poder Público deve ser apta para o atingimento dos fins que a inspiraram. Trata-se, em síntese, da aferição da 
idoneidade do ato para a consecução da finalidade perseguida pelo Estado. A análise cinge-se, assim, à existência de uma relação congruente entre meio e fim na medida examinada. Nessa linha, quando o juiz vai verificar a observância, por determinada norma, do subprincípio da adequação, ele deve, em primeiro lugar, perquirir quais os fins almejados pelo legislador ao editar tal norma. Em seguida, ele tem que analisar se a norma presta-se, ao menos em tese, para a consecução dos resultados colimados pelo legislador. ${ }^{32}$

Nesse primeiro subcritério já existe, portanto, uma relação entre meio e objetivo. Este não precisa, porém, ser, com certeza, de fato alcançado. Exclui-se, apenas de forma negativa, quando se tratar de um meio completamente inapto. Nesse sentido, o próprio BVerfG avalia se o meio é, e.g., pura e simplesmente inadequado (schlechthin ungeeignet) ou fundamentalmente inadequado (grundsätzlich ungeeignet), sendo suficiente até mesmo uma adequação meramente parcial. ${ }^{33}$ Por conseguinte, a adequação de um meio, via de regra, não é negada. ${ }^{34}$

Com frequência e, especialmente, em relação a medidas ainda não concluídas, os controles da adequação e da necessidade dependem consideravelmente de prognósticos. Neste ponto, a avaliação da adequação também tem significados diferentes para a Administração Pública e para o legislador, o qual goza de uma prerrogativa de avaliação em relação à primeira. Enquanto a aptidão de uma medida da Administração, para alcançar a meta perseguida, é completamente controlável, reconhece-se, especialmente quando é necessário suposição sobre desenvolvimento futuro, uma considerável margem para prognóstico do legislador, a qual desempenha um papel importante, e.g., para leis que buscam regular processos econômicos ou ambientais. ${ }^{35}$ Por certo, o prognóstico não pode ser aleatório e deve, na maior medida possível, basear-se em estudos empíricos.

32 SARMENTO, Daniel. A ponderação de interesses na Constituição Federal. Rio de Janeiro: Lumen Juris, 2003. p. 87.

33 Cf., respectivamente, BVerfGE 19, 119 (127) e E 70, 1 (26); E 85, 191 (212); referente à adequação parcial: BVerfGE 16, 147 (183); E 73, 301 (317). Cf., ainda, HIRSCHBERG, Lothar. Der Grundsatz der Verhältnismäßigkeit. Göttingen: Otto Schwartz \& Co, 1981. p. 51-52; STERN, Klaus. Das Staatsrecht der Bundesrepublik Deutschland. München: Beck, 2000. t. III/2. p. 776.

34 Hirschberg comprova, com numerosas referências jurisprudenciais que, por um lado, a adequação serve, na prática judicial, para barrar somente casos extremos de meios incorretos do legislador, mas que, por outro lado, realiza-se uma avaliação abrangente da adequação junto ao princípio da necessidade (HIRSCHBERG, Lothar. Der Grundsatz der Verhältnismäßigkeit. Göttingen: Otto Schwartz \& Co, 1981. p. 55-56 e 59 et seq.).

35 STERN, Klaus. Das Staatsrecht der Bundesrepublik Deutschland. München: Beck, 2000. t. III/2. p. $777-$ 778. 
Havendo, contudo, fundada divergência sobre a adequação, prevalece a decisão política do legislador democrático. ${ }^{36}$

Neste contexto, cabe, contudo, ressaltar que há autores que chegam a considerar que uma lei somente deva ser declarada inadequada e, portanto, inconstitucional, quando a previsão do legislador, com esgotamento das possibilidades de conhecimento quando da promulgação da lei, se basear em prognóstico evidentemente errado e, até mesmo, que o "mero" fato de que a inadequação se torne posteriormente manifesta não seria suficiente para a declaração de inconstitucionalidade. ${ }^{37}$ Tendo em vista que estamos tratando de restrições a direitos fundamentais, consideramos, data venia, que referida perspectiva não se justifica. Restando clara a inadequação da medida, não se pode exigir que o titular da liberdade aceite a restrição. Neste sentido, julgamos perfeitamente possivel e salutar reavaliar a adequação de decisões políticas pretéritas, com base na experiência vivenciada, como, a propósito, ocorre, atualmente, no STF, em relação à política de criminalização do aborto ou de "guerra às drogas".

\subsection{Necessidade: relação meio-meio}

A necessidade (ou exigibilidade) requer o emprego da intervenção adequada que seja menos gravosa. Assim, não pode o objetivo colimado ser alcançável por outro meio igualmente eficaz, mas menos prejudicial. Dito ainda de outra forma, não pode existir um meio alternativo mais ameno, com a mesma aptidão de êxito. Estes prerrequisitos devem ser determinados sempre em referência à realização dos direitos fundamentais. Por conseguinte, uma medida que restrinja um direito fundamental é necessária, quando não exista qualquer alternativa que intervenha menos no objeto protegido por ele e que, ao mesmo tempo, mantenha a probabilidade de se alcançar a meta no mesmo ou maior grau que a medida adotada. ${ }^{38}$ Em relação a este subprincípio, assevera Sarmento:

36 Cf., a propósito, DIMOULIS, Dimitri; MARTINS, Leonardo. Teoria geral dos direitos fundamentais. 2. ed. São Paulo: Revista dos Tribunais, 2009. p. 188-190.

37 Cf., e.g., STERN, Klaus. Das Staatsrecht der Bundesrepublik Deutschland. München: Beck, 2000. t. III/2. p. 778; BARROS, Suzana de Toledo. O princípio da proporcionalidade e o controle de constitucionalidades das leis restritivas de direitos fundamentais. 3. ed. Brasília: Brasília Jurídica, 2003. p. 80; HIRSCHBERG, Lothar. Der Grundsatz der Verhältnismäßigkeit. Göttingen: Otto Schwartz \& Co, 1981. p. 52-53.

38 Alexy, por sua vez, aborda este prerrequisito com referência ao caráter de princípio (da maioria) dos direitos fundamentais, realizáveis tendo em vista também as possibilidades fáticas (além das jurídicas), e ressaltando que entre dois meios que são igualmente adequados para produzir ou promover uma meta, fundamentada por um princípio, escolhe-se aquele que prejudica menos ou nada a realização do que o outro princípio exige (ALEXY, Robert. Theorie der Grundrechte. Frankfurt a.M: Suhrkamp, 1994. p. 101102). 
O princípio da necessidade ou exigibilidade, por sua vez, impõe que o Poder Público adote a medida menos gravosa possível para atingir determinado objetivo. Assim, se há várias formas possíveis de chegar ao resultado pretendido, o legislador ou administrador tem de optar por aquela que afete com menor intensidade os direitos e interesses da coletividade em geral. ${ }^{39}$

Nestes dois prerrequisitos da necessidade (menor gravidade e igual adequação) é onde aparece, de modo mais claro, a ideia que permeia a proibição de excesso: "poupar a liberdade tutelada pelo direito fundamental ao máximo possível". ${ }^{40}$ Para a busca de alternativas é fundamental levar em conta experiências jurídicas do passado, soluções adotadas em outros ordenamentos jurídicos, bem como pesquisas empíricas e materiais colhidos no debate entre especialistas. ${ }^{41}$ Vale pontuar, ainda, que eventuais meios alternativos buscados no exame da exigibilidade tampouco podem implicar mais custos para o Estado.

Divergências na capacidade de êxito são aceitas por parte da doutrina, quando se trate de um meio muito menos prejudicial para o direito fundamental e que tenha quase a mesma perspectiva de êxito. ${ }^{42}$ Similarmente, há autores que admitem a cogitação de meios mais onerosos, isto é, que impliquem maior investimento estatal, colocando-se, no entanto, neste caso, por certo, que a questão do quantum de maior onerosidade seria admissível. ${ }^{43}$

O controle da necessidade é o único momento da avaliação da proporcionalidade em que a intervenção será examinada com vistas a meios alternativos. Por outro lado, como o estabelecimento de metas dos atos estatais não é função dos tribunais, não há espaço para qualquer especulação de metas alternativas. A prerrogativa de avaliação do legislador na questão da adequação tem, portanto, necessariamente, também aqui, efeito. Enquanto para leis é decisivo o fim

39 SARMENTO, Daniel. A ponderação de interesses na Constituição Federal. Rio de Janeiro: Lumen Juris, 2003. p. 88.

40 DIMOULIS, Dimitri; MARTINS, Leonardo. Teoria geral dos direitos fundamentais. 2. ed. São Paulo: Revista dos Tribunais, 2009. p. 193-194.

41 DIMOULIS, Dimitri; MARTINS, Leonardo. Teoria geral dos direitos fundamentais. 2. ed. São Paulo: Revista dos Tribunais, 2009. p. 197.

42 Segundo Wendt, deve-se avaliar se com uma insignificante menor adequação não se ganha muito mais em liberdade (WENDT, Rudolf. Der Garantiegehalt der Grundrechte und das Übermaßverbot. Archiv des öffentlichen Rechts (AöR), Tübingen, v. 104, p. 414-474, 1979. p. 467). Isso, porém, não pode ser deduzido das formulações do BVerfG e do STF, que exigem meio alternativo “igualmente eficaz” (HC no 82.424-2). Cf., assim, opinião contrária em MICHAEL, Lothar. Die drei Argumentationsstrukturen des Grundsatzes der Verhältnismäßigkeit - Zur Dogmatik des Über- und Untermaßverbotes und der Gleichheitssätze. Juristische Schulung (JuS), München e Frankfurt a.M, ano 41, n. 2, p. 148-155, fev. 2001. p. 149.

43 DIMOULIS, Dimitri; MARTINS, Leonardo. Teoria geral dos direitos fundamentais. 2. ed. São Paulo: Revista dos Tribunais, 2009. p. 199-200. 
determinado autonomamente pelo legislador, para medidas da Administração Pública, o objetivo prescrito por meio de lei é, em contrapartida, determinante.

No controle da necessidade, podem ser diferenciadas, por fim, situações complexas e simples. Tem-se uma situação simples quando estão em jogo somente dois princípios e dois sujeitos de direito (Estado/cidadão). Nas situações complexas, deve-se observar, ainda, que uma amenização da intervenção às custas de um terceiro trata-se de decisão política e sujeita-se ao controle da igualdade, bem como que, quando o meio escolhido puder alçar mais de um objetivo, consideram-se somente meios alternativos que possam alcançar os mesmos objetivos que o meio empregado. ${ }^{44}$

\subsection{Proporcionalidade em sentido estrito e ponderação de bens}

Especialmente problemático é o terceiro critério do princípio da proporcionalidade, o qual, entre outros, é denominado proporcionalidade em sentido estrito, razoabilidade e mandado de ponderação. A proporcionalidade em sentido estrito exige que a intervenção e a meta perseguida estejam numa relação razoável (ou conveniente) entre si, ou seja, corretamente sopesada e bem ponderada. Assim, segundo Barros, a proporcionalidade stricto sensu: "é de suma importância para indicar se o meio utilizado se encontra em razoável proporção com o fim perseguido. A ideia de equilíbrio entre valores e bens é exalçada”. ${ }^{45} \mathrm{Em}$ semelhante sentido, o STF afirma que, na proporcionalidade, há de se perquirir se o ato impugnado "estabelece uma relação ponderada entre o grau de restrição de um princípio e o grau de realização do princípio contraposto" (voto do Ministro Gilmar Mendes no julgamento do HC no 82.424-2 de 17.9.2003). O BVerfG também formula, de modo conciso, que uma limitação a direitos fundamentais deve "estar numa relação apropriada com o peso e o significado do direito fundamental" (BVerfGE $67,157 / 173)$.

Quanto mais intenso for o significado da intervenção para o indivíduo, mais importantes devem ser suas razões justificadoras. Para estabelecer esta relação conveniente, recorrem jurisprudência e doutrina majoritária à técnica da ponderação. Neste contexto, o BVerfG quer ainda, desde a decisão do caso Lüth

44 Cf., em relação a situações complexas, ALEXY, Robert. Theorie der Grundrechte. Frankfurt a.M: Suhrkamp, 1994. p. 101, nota 86; HIRSCHBERG, Lothar. Der Grundsatz der Verhältnismäßigkeit. Göttingen: Otto Schwartz \& Co, 1981. p. 70-72.

45 BARROS, Suzana de Toledo. O princípio da proporcionalidade e o controle de constitucionalidades das leis restritivas de direitos fundamentais. 3. ed. Brasília: Brasília Jurídica, 2003. p. 85. 
(BVerfGE 7, 198), reconhecer o significado constitucional da normatização dos direitos fundamentais na instituição de uma ordem objetiva de valores ou um "sistema de valores", no qual ponderações seriam imprescindíveis. Em conexão com este critério fala-se, além disso, em peso dos valores, princípios, bens jurídicos ou interesses, e de ponderação de bens, efeito recíproco (Wechse/wirkung), assim como em relação custo-benefício. ${ }^{46}$ Com frequência, são ponderados bens jurídicos protegidos por direitos fundamentais e interesses públicos ou gerais (benefício para a coletividade), mas também nas chamadas colisões entre direitos fundamentais realiza-se a ponderação.

Como as Constituições, no entanto, não estabelecem uma hierarquia de valores que pudesse servir como parâmetro para o supostamente obrigatório método da ponderação, é, via de regra, impossível delimitar, em abstrato, o significado dos bens atingidos. Por essa razão, são, ao contrário, consideradas, sobretudo, as circunstâncias específicas da situação de restrição. A ponderação é, portanto, sempre pautada pelo caso concreto, falando-se, tão somente, de pesos relativos. ${ }^{47}$

0 procedimento da ponderação desenvolve-se também em três etapas. ${ }^{48}$ $\mathrm{Na}$ primeira delas, fundamenta-se que a ponderação é necessária. Esse é o caso, quando, em tese, são relevantes diferentes "bens" constitucionais, os quais, se aplicados independentemente do(s) outro(s), levariam a resultados incompatíveis entre si (situação de tensão - Spannungslage). Aqui, são, portanto, verificados, em abstrato, quais interesses ou bens estão em jogo. A partir de seus significados fundamentais, efetua-se, então, primeiramente, uma avaliação jurídica dos bens e interesses protegidos, sem, no entanto, fixar uma relação de primazia em abstrato. Posteriormente, devem ser determinados seus pesos tendo em vista as circunstâncias do caso concreto. É, assim, averiguada concretamente a intensidade do prejuízo; ou seja, quão forte, quão frequente, quão longa etc. é a intervenção (meio) no direito fundamental, quanto é exigido do atingido, assim como o grau e a importância de se alcançar a meta e, com isso, o ganho concreto de bem-estar comum ou o interesse de terceiros. Por fim, deve-se analisar se

SARMENTO, Daniel. A ponderação de interesses na Constituição Federal. Rio de Janeiro: Lumen Juris, 2003. p. 89.

47 Neste ponto, Alexy faz uma associação entre os limites às restrições e o caráter de princípio, por ele atribuído, às normas de direitos fundamentais. Assim, para ele, uma restrição a direitos fundamentais é autorizada apenas quando os princípios concorrentes, no caso concreto, tiverem peso maior que o princípio do direito fundamental (ALEXY, Robert. Theorie der Grundrechte. Frankfurt a.M: Suhrkamp, 1994. p. 257).

48 Cf. MICHAEL, Lothar. Die drei Argumentationsstrukturen des Grundsatzes der Verhältnismäßigkeit - Zur Dogmatik des Über- und Untermaßverbotes und der Gleichheitssätze. Juristische Schulung (JuS), München e Frankfurt a.M, ano 41, n. 2, p. 148-155, fev. 2001. p. 150; STERN, Klaus. Das Staatsrecht der Bundesrepublik Deutschland. München: Beck, 2000. t. III/2. p. 819. 
os bens jurídicos concretamente atingidos estão numa relação desproporcional à meta alcançada ou a alcançar. Assim, é decidido a qual bem jurídico foi dado um valor maior ou como um ajuste (ou equalização) deve ser produzido.

Contudo, continua a existir um problema de parâmetro ou critério, o qual impõe a questão: em que terceira medida de referência devem os pesos ou valores ser aferidos, para poder-se afirmar que uma relação proporcional foi produzida? Com frequência, busca-se responder a este problema remetendo-se a uma ordem de valores ou estrutura de valores prescrita pela Constituição. Fala-se ainda de ponderação conforme o critério da proporcionalidade. ${ }^{49}$ Além disso, Alexy formula uma lei da ponderação, segundo a qual: “quanto maior o grau de não satisfação ou de detrimento de um princípio, maior deve ser a importância de se satisfazer o outro".50

Cumpre ressaltar, no entanto, que nenhum desses argumentos consegue apresentar um parâmetro para a ponderação. 0 recurso a uma ordem de valores dos direitos fundamentais ou da Constituição somente afirma um critério, não pode, no entanto, demonstrá-lo. Pelo contrário: não há que se falar em hierarquia entre as normas constitucionais. Da mesma forma, não faz sentido falar em ponderação conforme a proporcionalidade, afinal um critério para alguma coisa deve ser algo diferente do que a própria "coisa". ${ }^{51}$ Por fim, a lei da ponderação de Alexy incorre no mesmo problema: não há critérios jurídicos para a comparação da importância dos princípios. Trata-se, pelo contrário, de uma decisão política. Em virtude da impossibilidade de se encontrar um critério convincente de sopesamento e comparação, diversos são os autores que defendem a exclusão deste critério na avaliação da proporcionalidade ou, ainda, que ele seja utilizado somente para declarar inconstitucional tratamento gritantemente desproporcional ou que não respeite conteúdos mínimos dos direitos. ${ }^{52}$

Não pretendemos, no presente artigo, resolver esta controvérsia. Contudo, independentemente da posição que se tenha em relação à ponderação, por todo

49 STERN, Klaus. Das Staatsrecht der Bundesrepublik Deutschland. München: Beck, 2000. t. III/2. p. 785; SARMENTO, Daniel. A ponderação de interesses na Constituição Federal. Rio de Janeiro: Lumen Juris, 2003. p. 96.

50 ALEXY, Robert. Theorie der Grundrechte. Frankfurt a.M: Suhrkamp, 1994. p. 146.

51 ALEXY, Robert. Theorie der Grundrechte. Frankfurt a.M: Suhrkamp, 1994. p. 70.

52 DIMOULIS, Dimitri; MARTINS, Leonardo. Teoria geral dos direitos fundamentais. 2. ed. São Paulo: Revista dos Tribunais, 2009. p. 201-209; OLIVEIRA, Renata Camilo de. Zur Kritik der Abwägung in der Grundrechtsdogmatik: Beitrag zu einem liberalen Grundrechtsverständnis im demokratischen Rechtsstaat. Berlim: Duncker \& Humblot, 2013. p. 320, 327-329; PIEROTH, Bodo; SCHLINK, Bernhard. Direitos fundamentais. São Paulo: Saraiva, 2012. p. 141-143; 146-148. Mesmo Virgílio Afonso da Silva, que, com base na teoria de Robert Alexy, busca defender a racionalidade da ponderação, argumenta que, somente em casos mais complexos, deve-se proceder à análise da proporcionalidade em sentido estrito (SILVA, Virgílio Afonso da. O proporcional e o razoável. Revista dos Tribunais, São Paulo, ano 91, n. 798, p. 23-50, abr. 2002. p. 35). 
o exposto, fica claro que ignorar a estrutura argumentativa aqui apresentada, partindo somente para uma "ponderação de valores colidentes" significa um reducionismo, que minimiza o arsenal para a defesa das liberdades (como a exigência de um fundamento constitucional para a restrição e da atuação do legislador) e ignora as especificidades de cada direito fundamental e, com isso, os parâmetros estabelecidos pela própria Constituição.

\section{Conclusão}

Como direitos de defesa (negativos, de resistência ou de liberdade), os direitos fundamentais proíbem intervenções não justificadas do Estado nas esferas individuais de liberdade, de forma que os indivíduos têm o poder de exercer positivamente essas liberdades e de exigir omissões dos poderes públicos, para evitar agressões lesivas a elas. É exatamente neste contexto que a clássica e principal aplicação do princípio da proporcionalidade ganha relevo, isto é, como proibição de excesso em face de intervenções estatais na liberdade ou privacidade. 0 princípio da proporcionalidade configura, no entanto, apenas um dos elementos (ainda que importante), de um modelo dogmático mais abrangente e complexo dos direitos de defesa. Este modelo, também denominado estrutura tríade, abrange uma análise do âmbito de proteção, da intervenção e de sua justificativa, que compreende o exame das restrições e dos limites às restrições.

Assim, o primeiro passo na aplicação dos direitos fundamentais é sempre a verificação e a delimitação do seu específico âmbito de proteção, isto é, da fração da realidade, na qual a proteção deve operar e que pode abranger diferentes ações, estados ou posições jurídicas. Referida delimitação deve ser feita de modo individualizado para cada direito fundamental. Posteriormente, é constatado se, e em que medida, um ato do Estado representa uma intervenção (ou ingerência) no âmbito de proteção. Tem-se uma intervenção sempre que um ato estatal (lei, ato administrativo ou decisão judicial) atuar de forma restritiva no âmbito de proteção de um direito fundamental. Sendo a intervenção confirmada, devem ser averiguadas suas possíveis justificativas, ou seja, se, e em que medida, ela é determinada pela própria Constituição, ou é por ela autorizada, e se as condições desta autorização foram cumpridas (fundamento constitucional)..$^{53}$

Para os diversos direitos fundamentais existem diferentes autorizações para intervenções, havendo direitos fundamentais com reserva de lei simples,

53 BÖCKENFÖRDE, Ernst-Wolfgang. Schutzbereich, Eingriff, verfassungsimmanente Schranken: Zur Kritik gegenwärtiger Grundrechtsdogmatik. Der Staat, Berlim, v. 42, n. 1-4, p. 165-192, 2003. p. 166. 
qualificada e sem reserva de lei. A reserva de lei simples existe nos direitos fundamentais em que a intervenção deve ocorrer meramente por ou com base em lei, sem que sejam impostas maiores exigências à respectiva legislação restritiva. Já a reserva de lei qualificada não apenas autoriza que a intervenção ocorra por ou com base em lei, mas impõe também que a intervenção esteja relacionada a situações específicas, que sirva a certos objetivos ou que utilize determinados meios. Especialmente difícil é a questão da limitação dos direitos fundamentais sem reserva de lei, que, segundo a proposta aqui defendida, só podem ser restringidos com base em direito fundamental colidente (e, não, qualquer "bem" ou "valor" constitucional). Somente após estas etapas, e desde que exista um fundamento para a intervenção, o princípio da proporcionalidade é trazido à discussão.

Trata-se, no princípio da proporcionalidade, de uma análise da relação entre meios e fins de atos do Estado. Ele exige que uma intervenção num direito fundamental (meio) seja adequada, necessária e proporcional em sentido estrito para alcançar uma meta legítima. Também neste ponto cumpre observar a necessidade de se desenvolver uma dogmática especial para cada um dos direitos fundamentais, que, como no caso dos direitos fundamentais com reserva de lei qualificada e sem reserva de lei, deve contemplar eventuais requisitos específicos quanto aos meios que podem ser utilizados e/ou fins que podem ou devem ser perseguidos. Sendo o meio e o fim legítimos, o critério da adequação exige somente que o meio empregado (isto é, a intervenção), efetivamente, fomente a meta. A necessidade impõe, por sua vez, o emprego da intervenção adequada que seja mais amena. Em outras palavras, o objetivo colimado não pode ser alcançável por outro meio igualmente eficaz, mas menos gravoso para o titular do direito fundamental.

Especialmente problemático é, por fim, o terceiro elemento do princípio da proporcionalidade, denominado proporcionalidade em sentido estrito (razoabilidade ou mandado de ponderação). Ele exige que a intervenção e a meta perseguida estejam numa relação razoável entre si, ou seja, corretamente sopesada e bem ponderada. Quanto mais intenso for o significado da intervenção para o indivíduo, mais importantes devem ser suas razões justificadoras. Cumpre ressaltar, no entanto, que, em virtude da impossibilidade de se encontrar critérios convincentes de sopesamento e comparação da importância de princípios, há autores que defendem a exclusão deste critério na avaliação da proporcionalidade ou, ainda, que ele seja utilizado somente para declarar inconstitucional tratamento gritantemente desproporcional ou que não respeite conteúdos mínimos dos direitos. 
Independentemente da posição que se tenha em relação à ponderação, o presente artigo pretendeu demonstrar que o princípio da proporcionalidade, na verdade, se insere em uma estrutura argumentativa bastante complexa e diferenciada. Assim, partir somente para uma "ponderação de valores colidentes", ignorando esta estrutura, significa um reducionismo, que suplanta o arsenal para a defesa das liberdades, amplia a discricionariedade dos órgãos aplicadores do direito e ignora as especificidades de cada direito fundamental e, com isso, os parâmetros estabelecidos pela própria Constituição.

Em contraposição, o arcabouço apesentado pretende fazer jus tanto à exigência de que nossas liberdades sejam levadas a sério, como ao fato de que intervenções estatais são necessárias, não existindo esfera social ou econômica que não seja passivel de intromissões estatais. Neste sentido, o modelo tem como premissa a possibilidade de limitações, mas que devem, necessariamente, ter a chancela do Legislativo (princípio democrático) e perseguir, de modo racional do ponto de vista fático, determinado objetivo e desde que sejam observados os parâmetros estabelecidos na Constituição. Diferentemente da lógica da colisão e ponderação, referido modelo permite ainda voltar a reconstruir o que é espaço de decisão do legislador democrático e possibilidade de controle da jurisdição constitucional.

Cumpre observar, no entanto, que o resultado deste artigo é apenas uma proposta de estrutura argumentativa, que deve ser desenvolvida em dogmáticas específicas: para cada um dos direitos fundamentais é necessário refletir sobre a delimitação do âmbito de proteção, sobre os possíveis fundamentos constitucionais para intervenções, bem como sobre eventuais requisitos quanto aos meios que podem ser utilizados e/ou fins que podem ou devem ser perseguidos quando da limitação. Neste sentido, o princípio da proporcionalidade deve deixar de ser pensado como um mero critério genérico (e, ainda menos, equivalente à noção de ponderação) e deve ser atrelado aos parâmetros normativos criados pela Constituição para cada um dos direitos fundamentais e suas diferentes configurações.

\title{
Restrictions on liberties: principle of proportionality as ban on excessive measures in the dogmatic of fundamental rights
}

\begin{abstract}
Fundamental rights are not absolute, nor shall they be seen as values subjected to balancing and that tend to constantly collide with each other and with other values. Based on these assumptions, the article presents a theoretical research on comparative law, with an analysis of content of both German and Brazilian jurisprudence on the principle of proportionality, relating it to the argumentative model for dealing with the rights of defense, called triad structure. The hypothesis that underlies the work is that ignoring the complexity and controversies related to this structure, proceeding to a "balancing of colliding values", means a reductionism, which overcomes the arsenal for the defense
\end{abstract}


of the liberties, increases the discretion of the Law enforcement bodies and ignores the specificities of each fundamental right. As a result, the article addresses a quite complex argumentative structure, which examines the scope of protection and possible justifications for interferences with the different rights of defense, and which also contains controversial points, worthy of greater theoretical attention. In this sense, this structure, instead of representing a generic solution, constitutes a mere argumentative framework, which shall be pondered and developed, in a unique way, for each one of the fundamental rights.

Keywords: Rights of defense. Principle of proportionality. Triad structure. Balancing.

Table of contents: Introduction - 1 Rights of defense against state interference and ban on excessive measures - $\mathbf{2}$ Scope of protection and interference with fundamental rights $-\mathbf{3}$ Constitutional basis of the interference: statutory reservation and colliding fundamental right $\mathbf{- 4}$ Principle of proportionality as prohibition of excessiveness and its subprinciples - Conclusion - References

\section{Referências}

ALEXY, Robert. Theorie der Grundrechte. Frankfurt a.M: Suhrkamp, 1994.

BARROS, Suzana de Toledo. O princípio da proporcionalidade e o controle de constitucionalidades das leis restritivas de direitos fundamentais. 3. ed. Brasília: Brasília Jurídica, 2003.

BÖCKENFÖRDE, Ernst-Wolfgang. Schutzbereich, Eingriff, verfassungsimmanente Schranken: Zur Kritik gegenwärtiger Grundrechtsdogmatik. Der Staat, Berlim, v. 42, n. 1-4, p. 165-192, 2003.

BÖCKENFÖRDE, Ernst-Wolfgang. Zur Lage der Grundrechtsdogmatik nach 40 Jahren Grundgesetz. München: Carl Friedrich von Siemens Stiftung, 1990.

BONAVIDES, Paulo. O princípio constitucional da proporcionalidade e da proteção dos direitos fundamentais. Revista da Faculdade Livre de Direito do Estado de Minas Gerais, Belo Horizonte, v. 34, n. 34, p. 275-291, 1994.

CARVALHO, José Murilo de. Cidadania no Brasil. o longo caminho. 3. ed. Rio de Janeiro: Civilização Brasileira, 2002.

DIMOULIS, Dimitri; MARTINS, Leonardo. Teoria geral dos direitos fundamentais. 2. ed. São Paulo: Revista dos Tribunais, 2009.

DWORKIN, Ronald. Taking rights seriously. Cambridge, Mass.: Harvard University Press, 1977.

HABERMAS, Jürgen. Faktizität und Geltung: Beiträge zur Diskurstheorie des Rechts und des demokratischen Rechtsstaats. Frankfurt a.M.: Suhrkamp, 1998.

HIRSCHBERG, Lothar. Der Grundsatz der Verhältnismäßigkeit. Göttingen: Otto Schwartz \& Co, 1981.

LAURENTIIS, Lucas Catib de. Proporcionalidade no direito constitucional: origem, modelos e reconstrução. São Paulo: Malheiros, 2017.

MASTRODI, Josué. Ponderação de direitos e proporcionalidade das decisões judiciais. Revista Direito GV, v. 10, p. 577-595, 2014.

MENDES, Gilmar Ferreira; COELHO, Inocêncio Mártires; BRANCO, Paulo Gustavo Gonet. Curso de direito constitucional. 12. ed. São Paulo: Saraiva, 2017. 
MICHAEL, Lothar. Die drei Argumentationsstrukturen des Grundsatzes der Verhältnismäßigkeit - Zur Dogmatik des Über- und Untermaßverbotes und der Gleichheitssätze. Juristische Schulung (JuS), München e Frankfurt a.M, ano 41, n. 2, p. 148-155, fev. 2001.

MÜLLER, Friedrich. Die Positivität der Grundrechte: Fragen einer praktischen Grundrechtsdogmatik. 2. ed. Berlim: Duncker \& Humblot, 1990.

OLIVEIRA, Renata Camilo de. Zur Kritik der Abwägung in der Grundrechtsdogmatik: Beitrag zu einem liberalen Grundrechtsverständnis im demokratischen Rechtsstaat. Berlim: Duncker \& Humblot, 2013.

PIEROTH, Bodo; SCHLINK, Bernhard. Direitos fundamentais. São Paulo: Saraiva, 2012.

SARLET, Ingo Wolfgang; MARINONI, Luiz Guilherme; MITIDIERO, Daniel. Curso de direito constitucional. 7. ed. São Paulo: Saraiva, 2018.

SARMENTO, Daniel. A ponderação de interesses na Constituição Federal. Rio de Janeiro: Lumen Juris, 2003.

SILVA, José Afonso da. Aplicabilidade das normas constitucionais. 8. ed. São Paulo: Malheiros, 2012.

SILVA, Virgílio Afonso da. Direitos fundamentais: conteúdo essencial, restrições e eficácia. 2. ed. São Paulo: Malheiros, 2010.

SILVA, Virgílio Afonso da. o proporcional e o razoável. Revista dos Tribunais, São Paulo, ano 91, n. 798, p. 23-50, abr. 2002.

STERN, Klaus. Das Staatsrecht der Bundesrepublik Deutschland. München: Beck, 2000. t. III/2.

WENDT, Rudolf. Der Garantiegehalt der Grundrechte und das Übermaßverbot. Archiv des öffentlichen Rechts (AöR), Tübingen, v. 104, p. 414-474, 1979.

Informação bibliográfica deste texto, conforme a NBR 6023:2018 da Associação Brasileira de Normas Técnicas (ABNT):

OLIVEIRA, Renata Camilo de. Restrições às liberdades: princípio da proporcionalidade como proibição de excesso na dogmática dos direitos fundamentais. Direitos Fundamentais \& Justiça, Belo Horizonte, ano 14, n. 42, p. 429-454, jan./jun. 2020.

Recebido em: 10.02.2019

Pareceres: $12.05 .2019,17.02 .2020$

Aprovado em: 18.02.2020 